Прилози, Одд. мат. тех. науки, МАНУ, XXVII-XXVIII, 1-2 (2006-2007), стр. 67-91 Contributions, Sec. Math. Tech. Sci., MANU, XXVII-XXVIII, 1-2 (2006-2007), pp. 67-91

ISSN 0351-3246

UDC: 621.3 .049 .77

\title{
SENSITIVITY ANALYSIS OF THE BARBER FILTERS
}

\author{
Gordana Lukić
}

\begin{abstract}
A b s t r a c t: The sensitivity of different Barber filters is investigated. It has been found that the sensitivity depends on the orders of the filters and on the types of the applied approximations. The sensitivity of the Barber filters does not change essentially by increasing the order of the filter, as is shown in the paper.

A comparison between the sensitivity of traditional active filters of the second order and Barber filters of the second order is presented. Taken into consideration is the transfer function sensitivity with respect to time constant $T$ because the value of the time constant is the most unstable quantity. The advantage of the Barber filters is obvious in sensitivity, especially for Barber bandpass filters. Because of their low sensitivity Barber filters are very suitable to use in moving objects, like aeroplanes, satellites and rockets.
\end{abstract}

Key words: sensitivity analysis; Barber filters; transfer function; approximation; modulating frequency; Barber bandpass filter; Barber lowpass filter; active bandpass filter; active lowpass filter; quality factor $Q$; comparision

\section{INTRODUCTION}

Continual development of performance requirements towards a precision and stability of filter characteristics motivates the need to search for new systems and a profound analysis of existing systems where it is possible to realize the prescribed requirements on a disposable elementary base.

This article deals with sensitivity of the filters the block diagram of which was considered for the first time by N. F. Barber (Fig. 1) and published in 1947 [1]. In his honor, they are called Barber filters. 


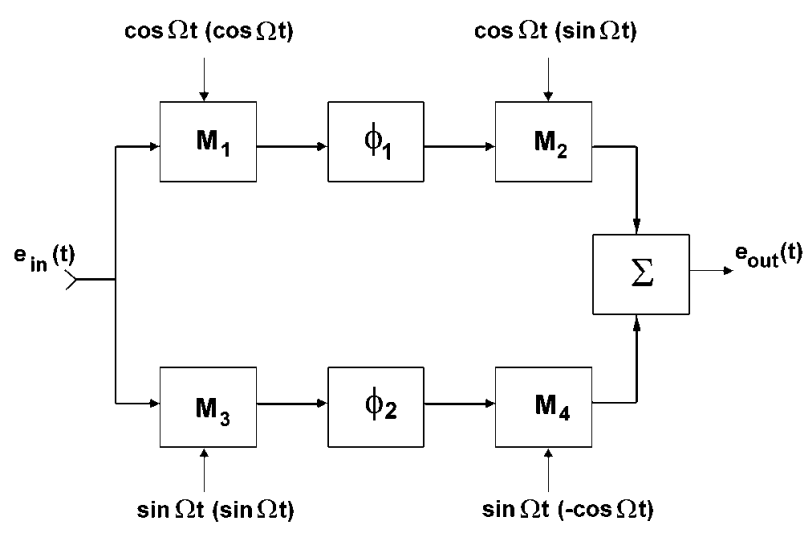

Fig. 1. The Barber filter

These filters were studied by Franks and Sandberg, [3], Madella [4], Kustov and Lundin [5], Langer [6], Möhrmann und Heinlein [7], Rigby [8], Kongelbeck and Szentirmai [9], but there have not been any studies in the last two decades. The reason for this can be found in their complex structures if they were realized with discrete elements. Nowadays, in view of the enormous development of technology, the realization of the Barber filters has become much simpler. Nevertheless, there is still a lack of basic understanding of these filters.

The next paragraph contains the material of the Barber bandpass filters and describe their transfer functions. Particular attention is paid to the sensitivity analysis if various approximations and filter orders are used. The third paragraph is structured similarly like the previous paragraph, but the Barber lowpass filters are considered. The goal of the comparison between Barber filters and traditional active filters, derived in the fourth paragraph, is to show the difference in sensitivity. In the last paragraph the advantages of the Barber filters are elicited.

\section{BARBER BANDPASS FILTER}

\section{A. Transfer function of Barber bandpass filters}

A Barber bandpass filter transfer function is presented in [2] (page 141) 


$$
W(p)=\frac{1}{2}[H(p-j \Omega)+H(p+j \Omega)]
$$

Let

$$
H_{1}(p)=H_{2}(p)=H(p)=\frac{\mathrm{K}}{A_{0}+\sum_{l=1}^{n} A_{l} p^{l}},
$$

where $A_{0}, A_{1}, \ldots, A_{n}$ are coefficients of approximation. In this case a Barber bandpass filter transfer function will be

$$
W(p)=\frac{\mathrm{K}}{2}\left[\frac{1}{A_{0}+\sum_{l=1}^{n} A_{l}(p-j \Omega)^{l}}+\frac{1}{A_{0}+\sum_{l=1}^{n} A_{l}(p+j \Omega)^{l}}\right],
$$

With $p=j \omega$ and $K=1$, from Eq. (3) we obtain the network function:

$$
W(j \omega)=\frac{1}{2}\left\{\frac{1}{A_{0}+\sum_{l=1}^{n} A_{l}\left[j(\omega-\Omega]^{l}\right.}+\frac{1}{A_{0}+\sum_{l=1}^{n} A_{l}\left[j(\omega+\Omega]^{l}\right.}\right\}
$$

In case that $n$ is an even natural number, from (4) follows:

$$
\begin{aligned}
& W(j \omega)=\frac{1}{2}\left[\frac{1}{A_{0}+\sum_{l=1}^{n / 2}(-1)^{l} A_{2 l}(\omega-\Omega)^{2 l}+j \sum_{l=1}^{n / 2} j^{2(l-1)} A_{2 l-1}(\omega-\Omega)^{2 l-1}}+\right. \\
& \left.+\frac{1}{A_{0}+\sum_{l=1}^{n / 2}(-1)^{l} A_{2 l}(\omega-\Omega)^{2 l}+j \sum_{l=1}^{n / 2} j^{2(l-1)} A_{2 l-1}(\omega+\Omega)^{2 l-1}}\right] .
\end{aligned}
$$

and if $n$ is an odd natural number (4) is:

Прилози, Одд. мат. тех. науки, XXVII-XXVIII, 1-2 (2006-2007), стр. 67-91 

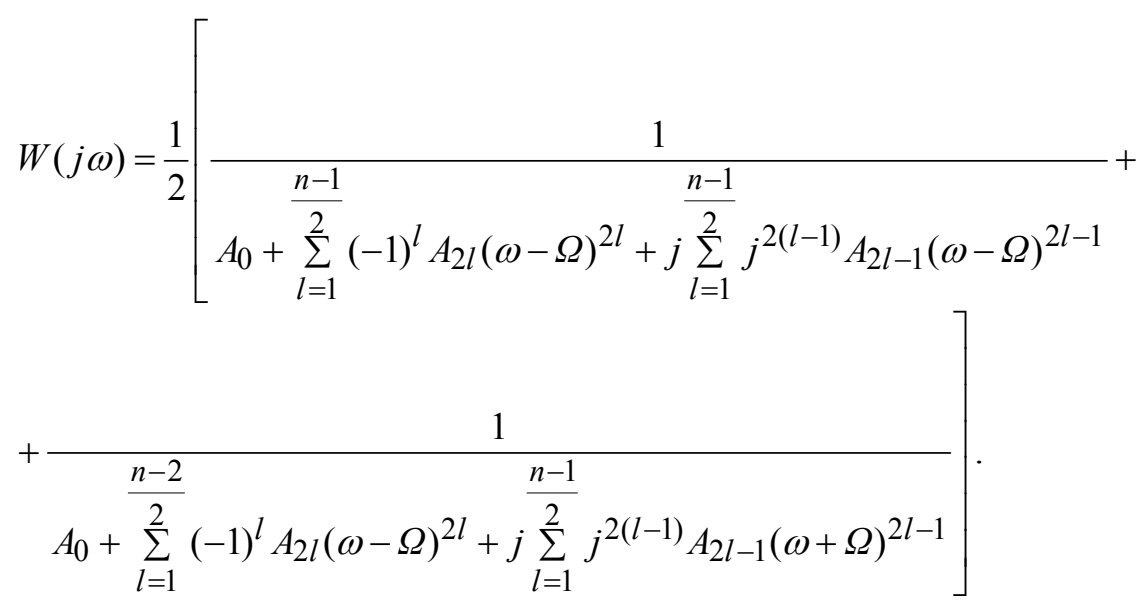

To simplify the writing of the expressions, we have introduced the following substitutions:

$$
\begin{aligned}
& \alpha=\omega-\Omega, \quad \beta=\omega+\Omega, \\
& B_{1}=A_{0}+\sum_{l=1}^{\frac{n}{2}}(-1)^{l} A_{2 l} \alpha^{2 l}, \quad C_{1}=A_{0}+\sum_{l=1}^{\frac{n-1}{2}}(-1)^{l} A_{2 l} \alpha^{2 l} \\
& B_{2}=\sum_{l=1}^{\frac{n}{2}} j^{2(l-1)} A_{2 l-1} \alpha^{2 l-1}, \quad C_{2}=\sum_{l=1}^{\frac{n+1}{2}} j^{2(l-1)} A_{2 l-1} \alpha^{2 l-1}, \\
& B_{3}=A_{0}+\sum_{l=1}^{\frac{n}{2}}(-1)^{l} A_{2 l} \beta^{2 l}, \quad C_{3}=A_{0}+\sum_{l=1}^{\frac{n-1}{2}}(-1)^{l} A_{2 l} \beta^{2 l} \\
& B_{4}=\sum_{l=1}^{\frac{n}{2}} j^{2(l-1)} A_{2 l-1} \beta^{2 l-1}, \quad C_{4}=\sum_{l=1}^{\frac{n+1}{2}} j^{2(l-1)} A_{2 l-1} \beta^{2 l-1} .
\end{aligned}
$$

From (5) and (7) we obtain the magnitude and the phase of the transfer function respectively: 


$$
\begin{gathered}
|W(j \omega)|=\frac{1}{2}\left[\left(\frac{B_{1}}{B_{1}^{2}+B_{2}^{2}}+\frac{B_{3}}{B_{3}^{2}+B_{4}^{2}}\right)^{2}+\left(\frac{B_{2}}{B_{1}^{2}+B_{2}^{2}}+\frac{B_{4}}{B_{3}^{2}+B_{4}^{2}}\right)^{2}\right]^{\frac{1}{2}}, \\
\varphi(\omega)=-\operatorname{arctg} \frac{\frac{B_{2}}{B_{1}^{2}+B_{2}^{2}}+\frac{B_{4}}{B_{3}^{2}+B_{4}^{2}}}{\frac{B_{1}^{2}+B_{2}^{2}}{B_{1}^{2}}+\frac{B_{3}}{B_{3}^{2}+B_{4}^{2}}}
\end{gathered}
$$

and from (6) and (7), (10) and (11) are obtained:

$$
\begin{gathered}
|W(j \omega)|=\frac{1}{2}\left[\left(\frac{C_{1}}{C_{1}^{2}+C_{2}^{2}}+\frac{C_{3}}{C_{3}^{2}+C_{4}^{2}}\right)^{2}+\left(\frac{C_{2}}{C_{1}^{2}+C_{2}^{2}}+\frac{C_{4}}{C_{3}^{2}+C_{4}^{2}}\right)^{2}\right]^{\frac{1}{2}}, \\
\varphi(\omega)=-\operatorname{arctg} \frac{\frac{C_{2}}{C_{1}^{2}+C_{2}^{2}}+\frac{C_{4}}{C_{3}^{2}+C_{4}^{2}}}{C_{1}^{2}+C_{2}^{2}}+\frac{C_{3}}{C_{3}^{2}+C_{4}^{2}}
\end{gathered}
$$

Figure 2 shows the amplitude - frequency responses and Fig. 3 shows the phase - frequency responses of the fourth-order Barber bandpass filter for various modulating frequency values. For the inner filter transfer functions the Butterworth approximation is used.

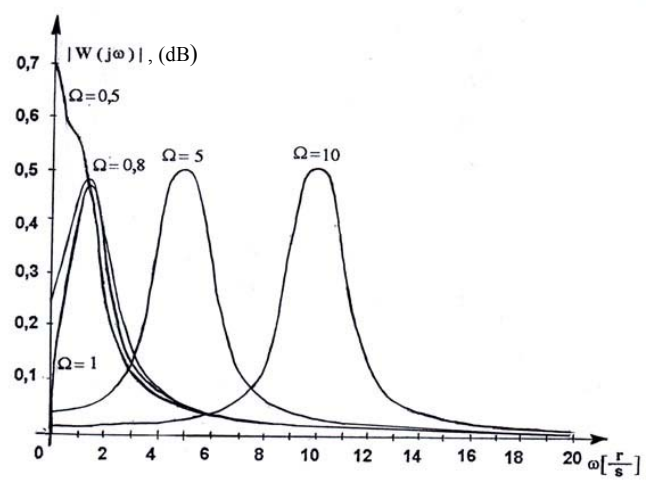

Fig. 2. Amplitude - frequency response of the fourth-order Barber bandpass filters (the Butterworth approximation)

Прилози, Одд. мат. тех. науки, XXVII-XXVIII, 1-2 (2006-2007), стр. 67-91 


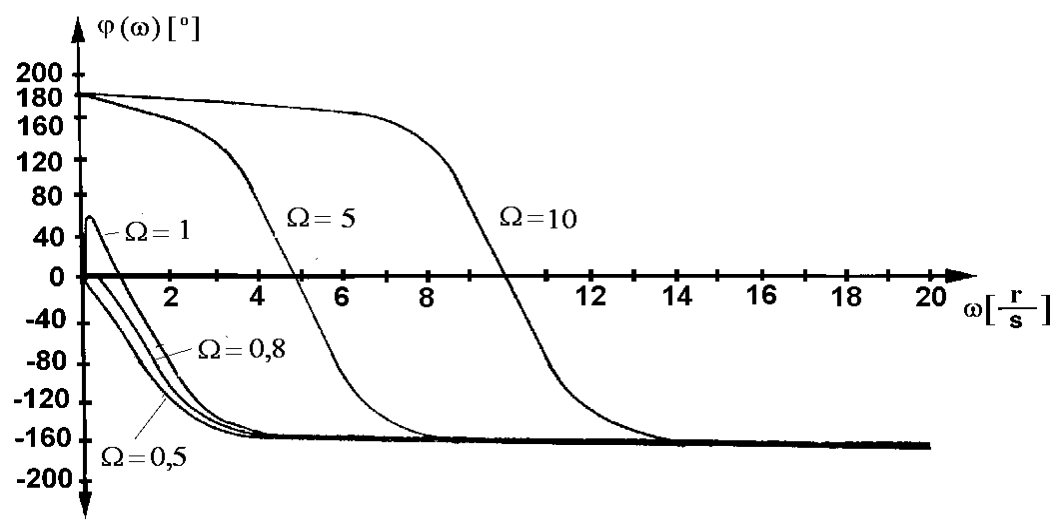

Fig. 3. Phase - frequency responses of the fourth-order Barber bandpass filters (the Butterworth approximation)

The amplitude - frequency responses and the phase - frequency responses of the sixth-order Barber bandpass filter for various modulating frequency values are plotted in Fig. 4 and Fig. 5. Inner filter transfer functions are approximated by the Chebysher approximation with the ripple of $0.5 \mathrm{~dB}$.

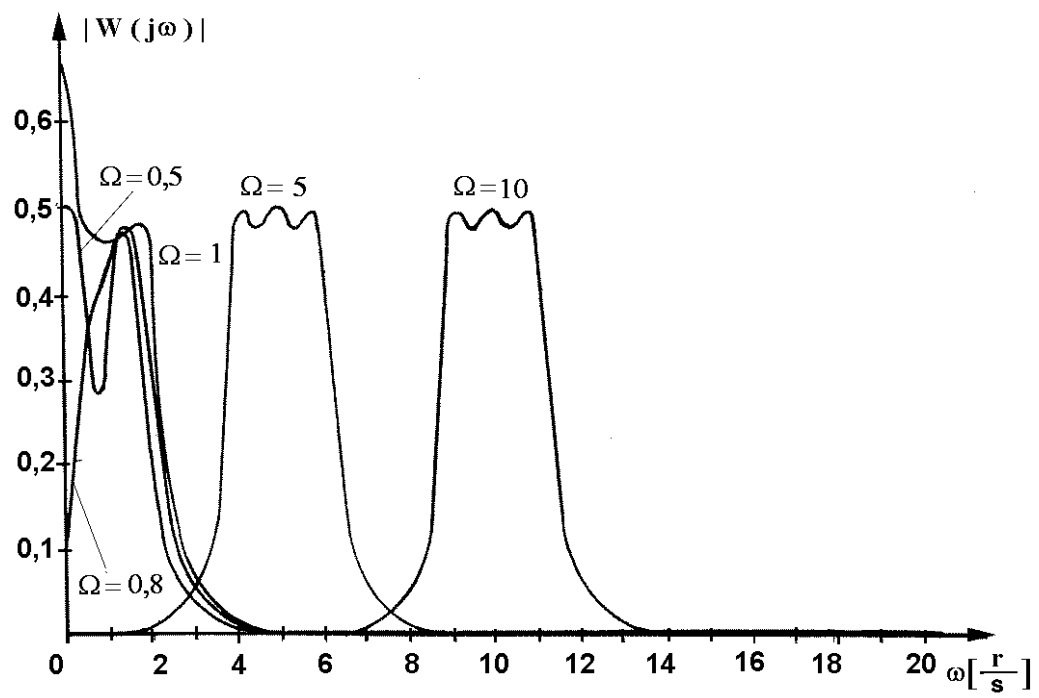

Fig. 4. Amplitude - frequency responses of the sixth-order Barber bandpass filters (the Chebyshev approximation with the ripple $0.5 \mathrm{~dB}$ ) 


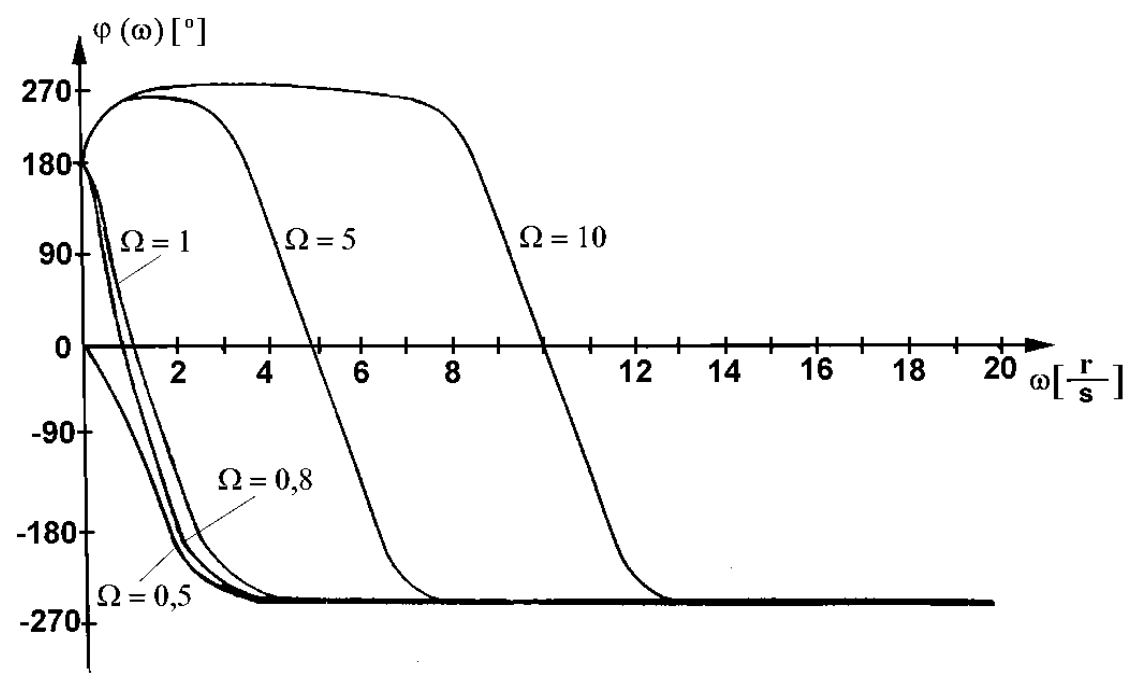

Fig. 5. Phase - frequency responses of the sixth-order Barber bandpass filters (the Chebyshev approximation with the ripple $0.5 \mathrm{~dB}$ )

Analyzing expressions (8) and (10) and considering Fig. 2 and Fig. 4 above, the following can be concluded: the amplitude - frequency response at $\omega=0$ differs from zero. Increasing the modulating frequency and the filter order, this value decreases. Besides, it is obvious that the passband does not depend on modulation frequency $\Omega$. The limits of AFC in the passband dictate a type of approximation and the order of filter. Stopband limits determine modulation frequency $\Omega$. If a modulation frequency increases, the symmetricalness of an AFC increases as well.

For low-frequency modulation values, undesirable sequences occur because of additional zero transmission. The influence of zero transmission decreases by increasing the modulation frequency $\Omega$.

The phase - frequency behavior characteristic of the Barber bandpass filter differs from the corresponding active filter PhFC. This difference is considerable for low values of modulation frequency. Besides, at the modulation frequency, the value of Barber bandpass filter PhFC differs from zero. This difference decreases when the modulation frequency and the order of filters increase.

Relation (5) at the modulation frequency can be written as follows: 


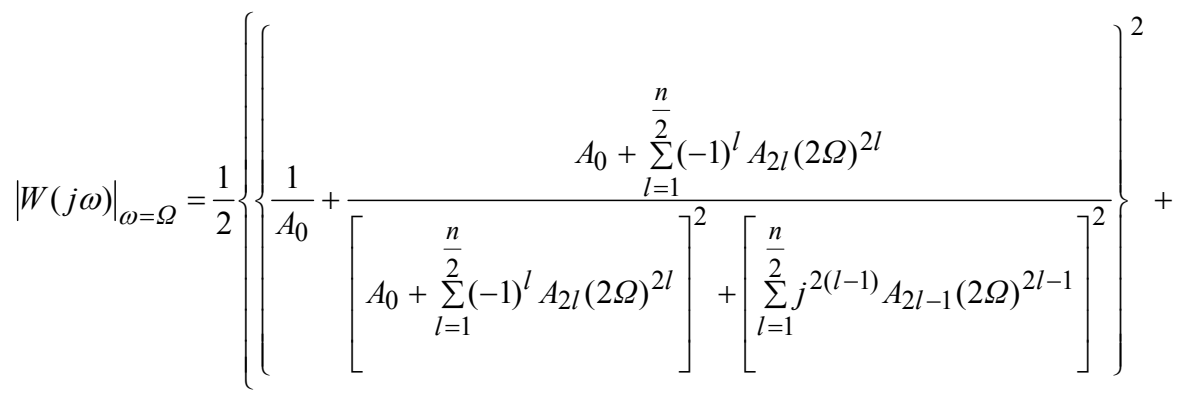

$$
\begin{aligned}
& \left.+\left\{\frac{\sum_{l=1}^{\frac{n}{2}} j^{2(l-1)} A_{2 l-1}(2 \Omega)^{2 l-1}}{\left[A_{0}+\sum_{l=1}^{\frac{n}{2}}(-1)^{l} A_{2 l}(2 \Omega)^{2 l}\right]^{2}+\left[\sum_{l=1}^{\frac{n}{2}} j^{2(l-1)} A_{2 l-1}(2 \Omega)^{2 l-1}\right]^{2}}\right\}^{2}\right\}^{\frac{1}{2}}
\end{aligned}
$$

Obviously,

$$
\lim _{\Omega \rightarrow \infty}|W(j \omega)|_{\omega=\Omega}=\frac{1}{2 A_{0}} .
$$

From (9) at $\omega=\Omega$, the following is true:

$$
\begin{gathered}
\left.\varphi(\omega)\right|_{\omega=\Omega}=-\operatorname{arctg} \frac{\sum_{l=1}^{\frac{n}{2}} j^{2(l-1)} A_{2 l-1}(2 \Omega)^{2 l-1}}{A_{0}+\sum_{l=1}^{\frac{n}{2}}(-1)^{l} A_{2 l}(2 \Omega)^{2 l}}, \\
\left.\lim _{\Omega \rightarrow \infty} \varphi(\omega)\right|_{\omega=\Omega}=0 .
\end{gathered}
$$

The same result can be obtained if the relations (10) and (11) are considered.

The above analysis shows that from the choice of modulation frequency $\Omega$ and approximation type of inner filter transfer functions, the required form of Barber bandpass filter frequency characteristics can be obtained. 


\section{B. Sensitivity of a Barber bandpass filter transfer function}

For the purposes of estimating acquired realization and its comparison with some other realizations corresponding to the same technical requirements, it is necessary to use a notion of filter sensitivity. The classical sensitivity (or Bode's sensitivity) is the most general estimation of an electrical network function changes $F(p)$ with respect to the parameter variation $q$.

$$
S_{q}^{F(p)}=\frac{d[\ln F(p)]}{d(\ln q)}=\frac{q}{F(p)} \cdot \frac{d[F(p)]}{d q} .
$$

Generally, a computation of filter sensitivity characteristics can be made in two steps. At the first step, the influence of instability of approximation transfer function coefficients is determined. At the second step, approximation coefficient sensitivity is determined by changes of elements realizing these coefficients.

Figs. 6, 7, 8, 9, 10 and 11 show graphically the magnitude and the phase sensitivity obtained as the results of the first step of the sensitivity computation because the second step makes sense when a filter device operates.

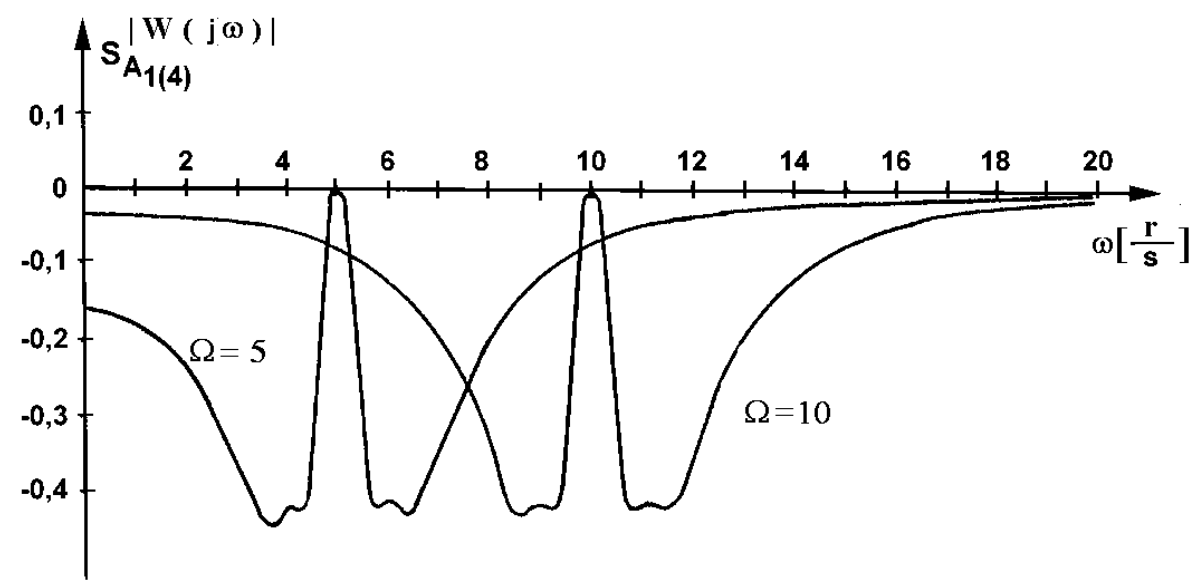

Fig. 6. Magnitude sensitivity of the fourth-order transfer function of Barber bandpass filter with respect to an approximation coefficient $A_{1}$ (the Butterworth approximation) 


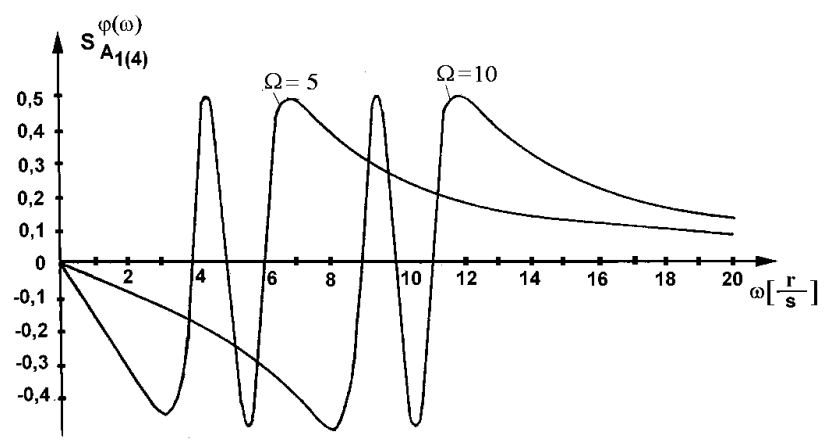

Fig. 7. Phase sensitivity of the fourth-order transfer function of Barber bandpass filter with respect to an approximation coefficient $A_{1}$ (the Butterworth approximation)

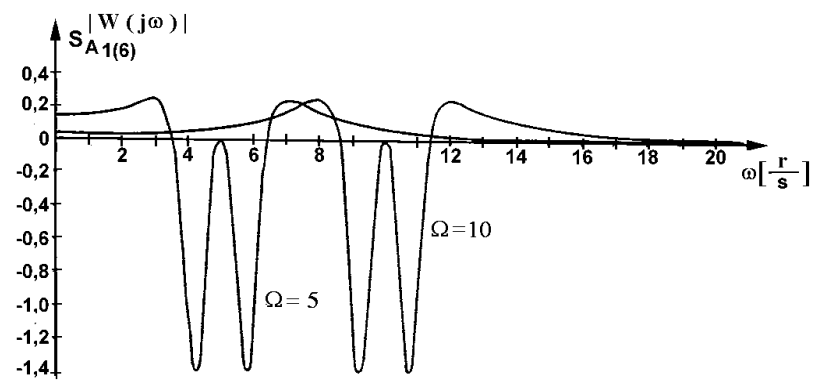

Fig. 8. Magnitude sensitivity of the sixth-order transfer function of Barber bandpass filter with respect to an approximation coefficient $A_{1}$ (the Butterworth approximation)

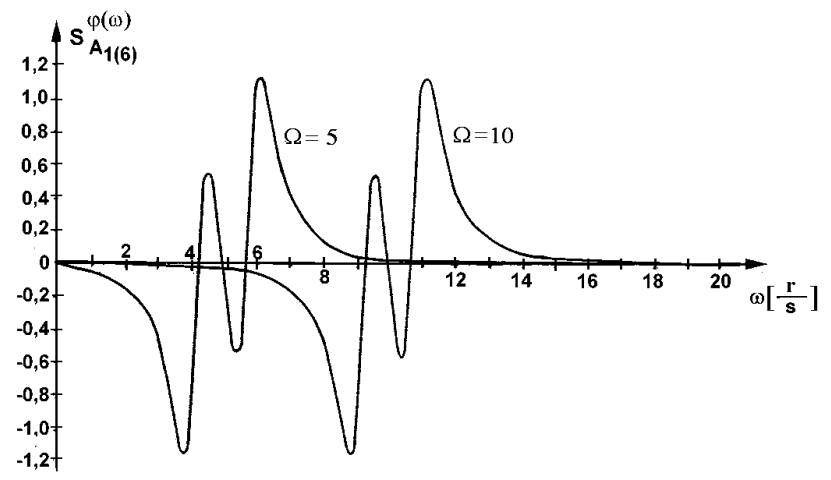

Fig. 9. Phase sensitivity of the sixth-order transfer function of Barber bandpass filter with respect to an approximation coefficient $A_{1}$ (the Butterworth approximation) 


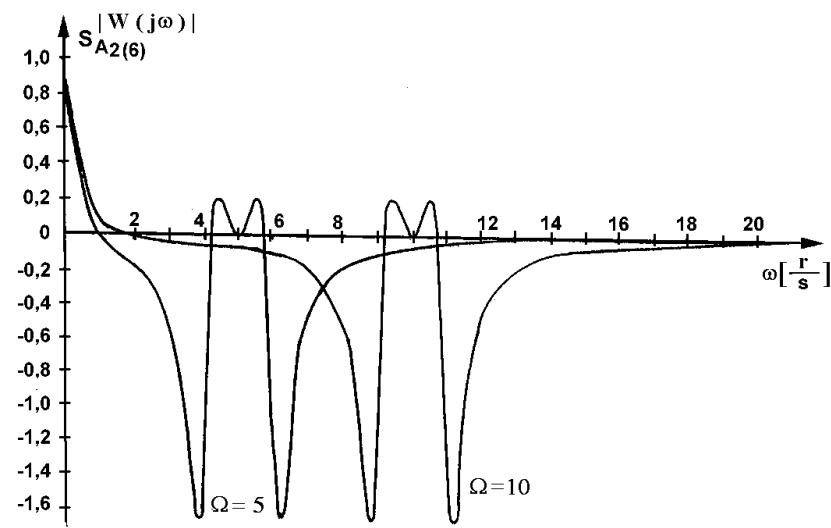

Fig. 10. Magnitude sensitivity of the sixth-order transfer function of Barber bandpass filter with respect to an approximation coefficient $A_{2}$ (the Chebyshev approximation)

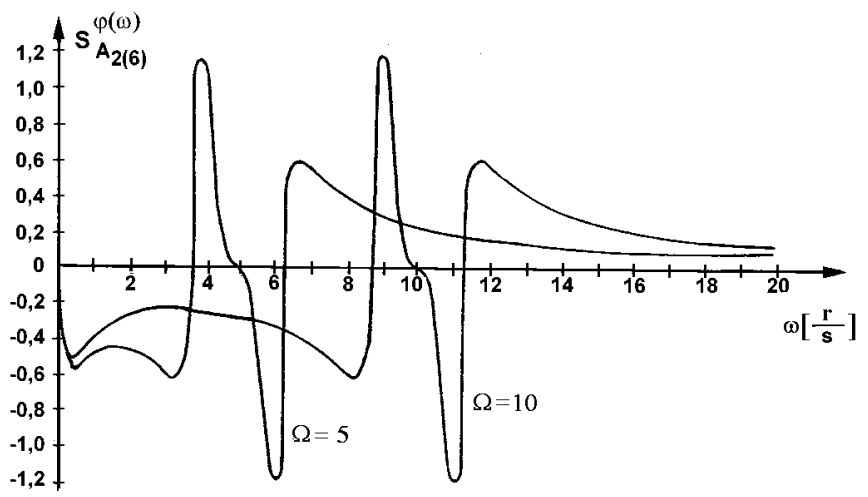

Fig. 11. Phase sensitivity of the sixth-order transfer function of Barber bandpass filter with respect to an approximation coefficient $A_{2}$ (the Chebyshev approximation)

Analysing the above graphs it is obvious that the magnitude and phase sensitivity do not depend on modulation frequency $\Omega$. Increasing the Barber filter order, the transfer function magnitude sensitivity with respect to approximation coefficients, increase in a passband. This increasing depends on the definite coefficient and an approximation type, but it is minor.

Increasing a filter order, phase sensitivity according to changes in the approximation coefficients does not increase considerably.

Прилози, Одд. мат. тех. науки, XXVII-XXVIII, 1-2 (2006-2007), стр. 67-91 


\section{BARBER LOWPASS FILTER}

\section{A. Transfer function of Barber lowpass filters}

In case of the higher-order Barber lowpass filters, an influence of additional zeros is so strong that they greatly deform filter characteristics. For this reason it does not make sense to consider Barber lowpass filters with the order higher than two.

Barber lowpass filter transfer function is given in [2] (page 141).

$$
Y(p)=\frac{1}{2 j}[H(p-j \Omega)-H(p+j \Omega)]
$$

Using equation (2) and assuming $n=1, A_{0}=1, A_{1}=T$, the Barber lowpass filter transfer function of the second order is obtained directly from (17):

$$
Y(p)=\frac{\kappa \Omega}{T\left[\left(p+\frac{1}{T}\right)^{2}+\Omega^{2}\right]}=\frac{\frac{\kappa \Omega}{T}}{p^{2}+\frac{2}{T} p+\frac{1}{T^{2}}+\Omega^{2}} .
$$

In this case a quality factor $Q$ is

$$
Q=0.5 \sqrt{1+\Omega^{2} T^{2}} .
$$

If $\kappa=1$ and $p=j \omega$, the magnitude and the phase are respectively

$$
\begin{gathered}
|Y(j \omega)|=\frac{\Omega T}{\sqrt{\left(1-\omega^{2} T^{2}+\Omega^{2} T^{2}\right)^{2}+4 \omega^{2} T^{2}}}, \\
\psi(\omega)=\operatorname{arctg} \frac{2 \omega T}{\sqrt{\left(1-\omega^{2} T^{2}+\Omega^{2} T^{2}\right)^{2}+4 \omega^{2} T^{2}}} .
\end{gathered}
$$

Considering $T=f(Q)$ from (19) and using frequency normalization

$$
\omega_{N}=\frac{\omega}{\Omega},
$$

magnitude and phase are given by 


$$
\begin{gathered}
\left|Y\left(j \omega_{N}\right)\right|=\sqrt{\frac{4 Q^{2}-1}{\left[4 Q^{2}-\omega_{N}^{2}\left(4 Q^{2}-1\right)\right]^{2}+4 \omega_{N}^{2}\left(4 Q^{2}-1\right)}}, \\
\psi\left(\omega_{N}\right)=\operatorname{arctg} \frac{2 \omega_{N} \sqrt{4 Q^{2}-1}}{\omega_{N}^{2}\left(4 Q^{2}-1\right)-4 Q^{2}} .
\end{gathered}
$$

The frequency responses of the amplitude and the phase of the second order Barber lowpass filters are represented by the expressions (20), (21), (23) and (24). In Fig. 12 and Fig. 13 their corresponding curves are presented. In Figs. 14, 15, 16 and 17, AFC and PhFC for $T=1$ are shown.

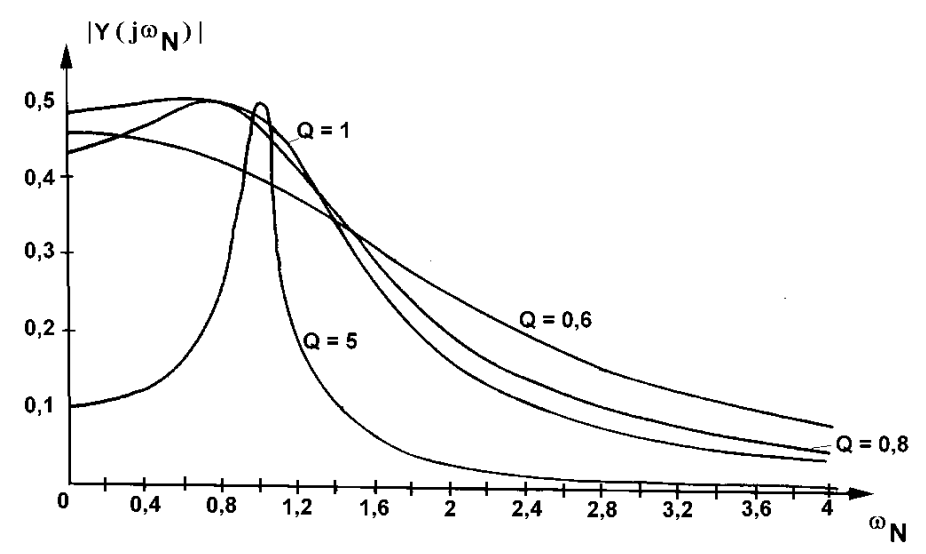

Fig. 12. Amplitude - frequency responses of the second order Barber lowpass filters

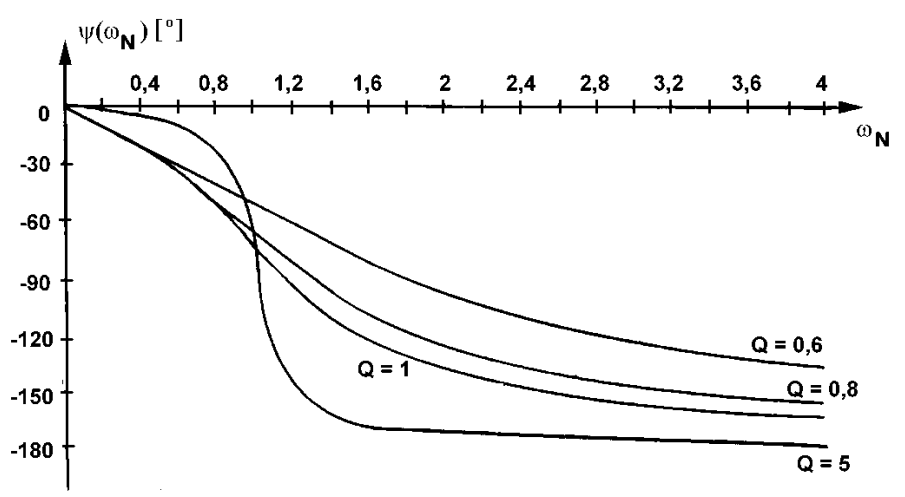

Fig. 13. Phase - frequency responses of the second order Barber lowpass filters 


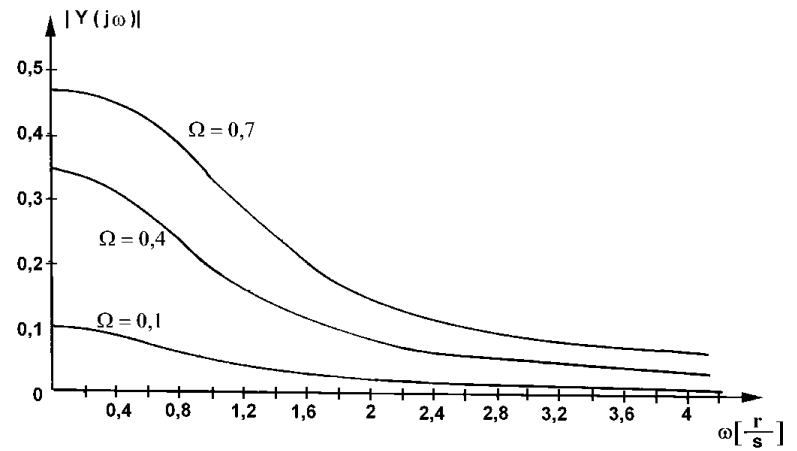

Fig. 14. Amplitude - frequency responses of the second order Barber lowpass filters for $\Omega<1$

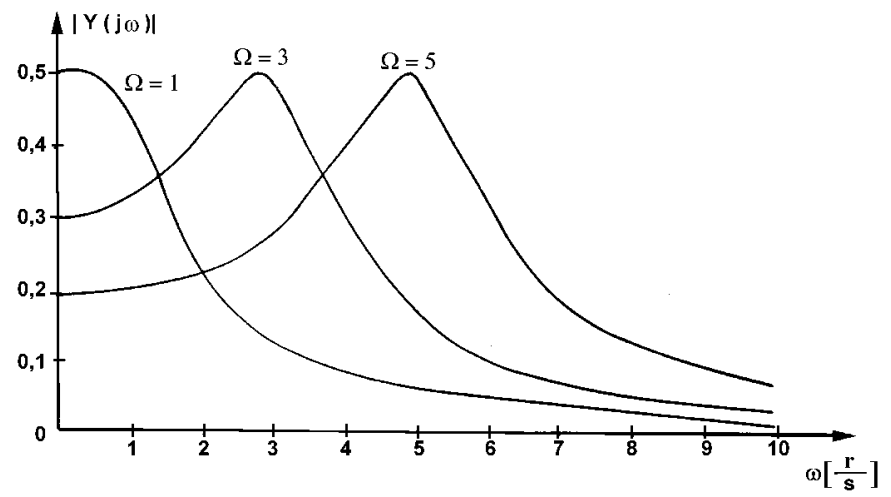

Fig. 15. Amplitude - frequency responses of the second order Barber lowpass filters for $\Omega \geq 1$

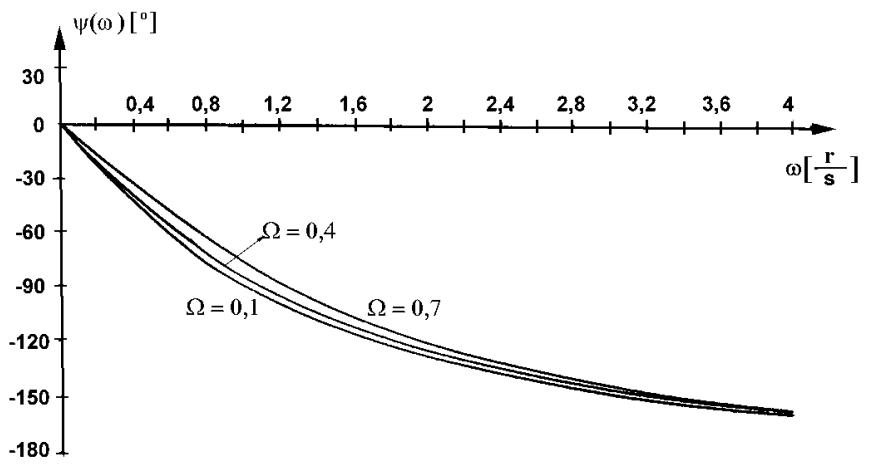

Fig. 16. Phase - frequency responses of the second order Barber lowpass filters for $\Omega<1$ 


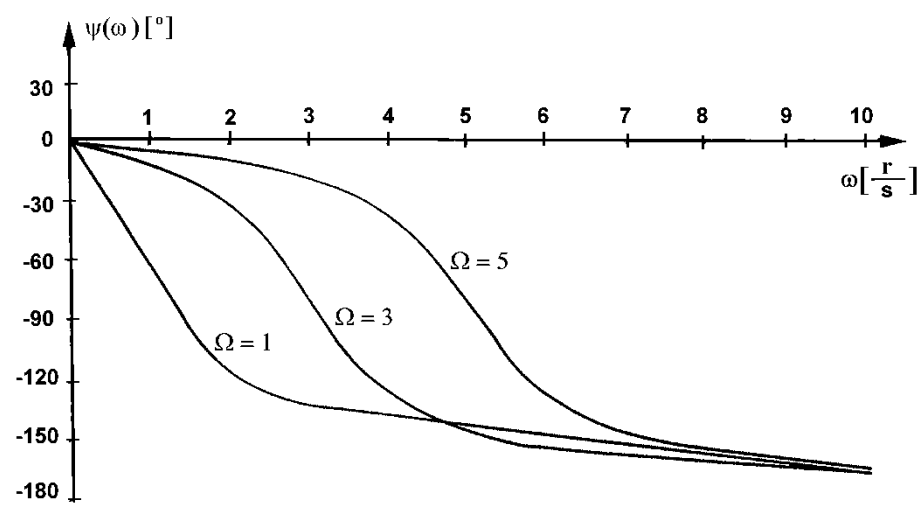

Fig. 17. Phase - frequency responses of the second order Barber lowpass filters for $\Omega \geq 1$

At the modulation frequency, (23) and (24) become respectively

$$
\begin{gathered}
\left|Y\left(j \omega_{N}\right)\right|_{\omega_{N}=1}=\sqrt{\frac{4 Q^{2}-1}{16 Q^{2}-3}}, \\
\left.\psi\left(\omega_{N}\right)\right|_{\omega_{N}=1}=-\operatorname{arctg}\left(2 \sqrt{4 Q^{2}-1}\right) .
\end{gathered}
$$

Evidently,

$$
\begin{gathered}
\lim _{Q \rightarrow \infty}\left|Y\left(j \omega_{N}\right)\right|_{\omega_{N}=1}=\frac{1}{2}, \\
\left.\lim _{Q \rightarrow \infty} \psi\left(\omega_{N}\right)\right|_{\omega_{N}=1}=-90^{\circ} .
\end{gathered}
$$

An examination of the above expressions and graphs for $T=1$ (see Fig. 14, Fig. 15 for $\Omega=1$ ), indicates that flat characteristics are achieved. As frequency increases, AFC monotonously decreases. If $\Omega \leq 1$ while the modulation frequency increases the value of transmission coefficient at the zero frequency increases as well. For $\Omega>1$, as seen in Fig. 15, AFC is very deformed. As follows from Fig. 12, the value of the $Q$-factor is determined by the required form of AFC.

PhFC begins (see Figs. 16 and 17) from zero and decreases as the frequency increases. It is linear in the passband and is asymptotically approaching $\left(-180^{\circ}\right)$. 


\section{B. Sensitivity of Barber lowpass filter transfer function of the second order}

Using the relations (16), (19), (20), and (22) the transfer function magnitude sensitivity with respect to the time constant $T$ can be derived as follows:

$$
S_{T}^{\left|Y\left(j \omega_{N}\right)\right|}=\frac{1-\left(4 Q^{2}-1\right)^{2}\left(\omega_{n}^{2}-1\right)}{\left[4 Q^{2}-\omega_{N}^{2}\left(4 Q^{2}-1\right)\right]^{2}+4 \omega_{N}^{2}\left(4 Q^{2}-1\right)} .
$$

Referring to Fig. 18, where $S_{T}^{Y Y\left(j \omega_{N}\right) \mid}$ is graphically shown (curves 1, 3, 5 at $Q=1, Q=3$ and $Q=5$ respectively), it is evident that the maximum absolute value of $S_{T}^{Y\left(j \omega_{N}\right) \mid}$ is 1 . Increasing $Q$-factor, $S_{T}^{\left|Y\left(j \omega_{N}\right)\right|}$ at the modulation frequency decreases.

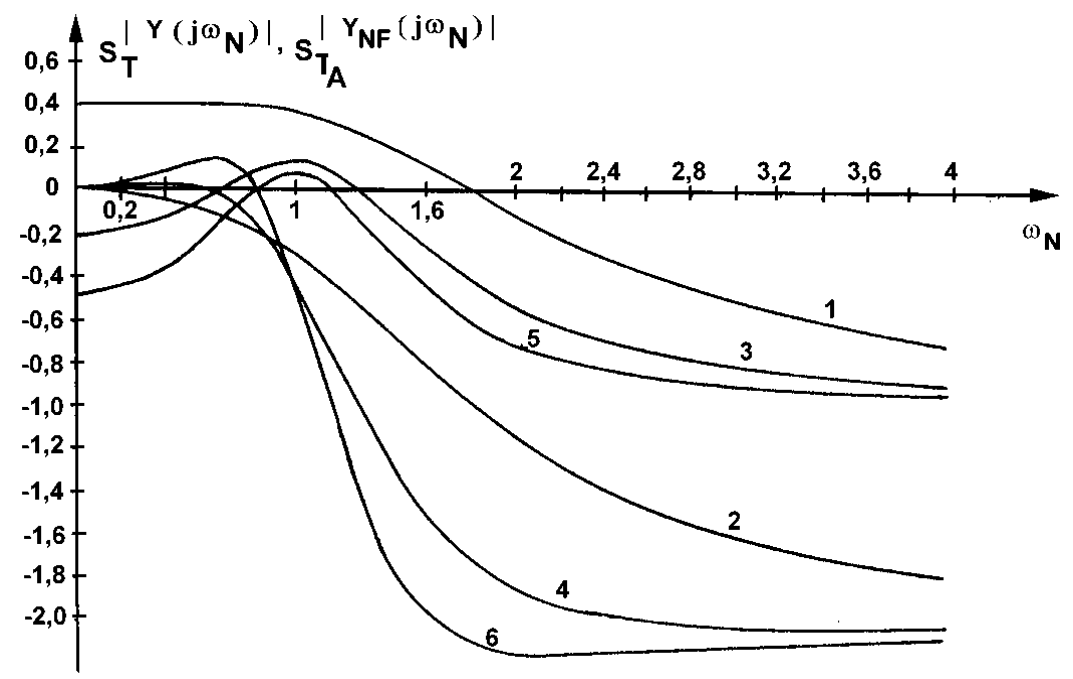

Fig. 18. Transfer function magnitude sensitivity of the second order Barber lowpass filters and the second order active lowpass filters

The phase sensitivity of a Barber lowpass transfer function of the second order with respect to changes of the time constant is achieved by the relations (16), (19), (21) and (22): 


$$
S_{T}^{\psi\left(\omega_{N}\right)}=\frac{2 \omega_{N} \sqrt{4 Q^{2}-1}\left[4 Q^{2}-\omega_{N}^{2}\left(4 Q^{2}-1\right)-2\right]}{\left[\omega_{N}^{2}\left(4 Q^{2}-1\right)-4 Q^{2}\right]^{2}+4 \omega_{N}^{2}\left(4 Q^{2}-1\right)} .
$$

Frequency behavior of $S_{T}^{\psi\left(\omega_{N}\right)}$ for various values of a $Q$-factor (curves $1,3,5$ at $Q=0.6, Q=0.8$ and $Q=1$ respectively) is represented in Fig. 19. The maximum absolute value of $S_{T}^{\psi\left(\omega_{N}\right)}$ is 0.9 .

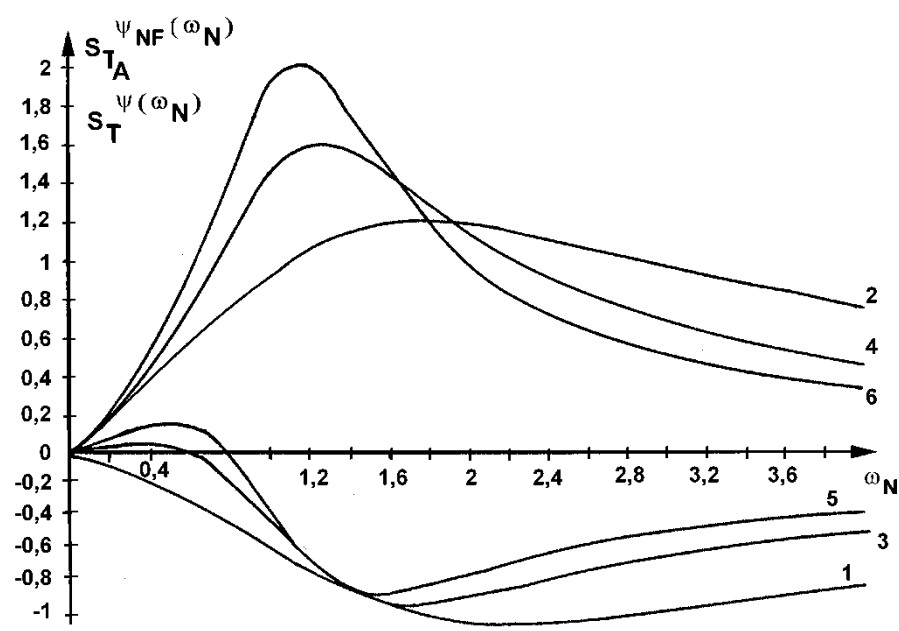

Fig. 19. Transfer function phase sensitivity of the second order Barber lowpass filters and the second order active lowpass filters

\section{COMPARISON BETWEEN BARBER FILTERS AND TRADITIONAL ACTIVE FILTERS}

It will be interesting to compare, for example, Barber bandpass filter sensitivity of the second order with a traditional active filter of the second order.

From (19) and (22) and at $n=1, A_{0}=1$ and $A_{1}=T$ ( $T$ is a time constant) in (3) magnitude and phase shift are given by:

Прилози, Одд. мат. тех. науки, XXVII-XXVIII, 1-2 (2006-2007), стр. 67-91 


$$
\begin{aligned}
& \left|W\left(j \omega_{N}\right)\right|=\sqrt{\frac{1+\omega_{N}^{2}\left(4 Q^{2}-1\right)}{\left[4 Q^{2}-\omega_{N}^{2}\left(4 Q^{2}-1\right)\right]^{2}+4 \omega_{N}^{2}\left(Q^{2}-1\right)}}, \\
& \varphi\left(\omega_{N}\right)=\operatorname{arctg} \frac{\omega_{N} \sqrt{4 Q^{2}-1}\left[4 Q^{2}-\omega_{N}^{2}\left(4 Q^{2}-1\right)-2\right]}{4 Q^{2}+\omega_{N}^{2}\left(4 Q^{2}-1\right)} .
\end{aligned}
$$

In this case it is useful to take into consideration the transfer function sensitivity with respect to time constant $T$. The choice of this parameter can be explained by the fact that in filters, especially variable ones, the value of the time constant is the most unstable quantity.

It is convenient to introduce the following substitutions:

$$
\begin{aligned}
& S_{1}=4 Q^{2}-1 ; \\
& S_{2}=4 Q^{2}-\omega_{N}^{2} S_{1} ; \\
& S_{3}=4 \omega_{N}^{2}\left(4 Q^{2}-1\right) ; \\
& S_{4}=1+\omega_{N}^{2}\left(4 Q^{2}-1\right) ; \\
& S_{5}=4 Q^{2}+\omega_{N}^{2}\left(4 Q^{2}-1\right) .
\end{aligned}
$$

From (16), (31) and (33) the transfer function magnitude sensitivity according to changes in the time constant of a Barber passband filter of the second order is obtained:

$$
S_{T}^{\left|W\left(j \omega_{N}\right)\right|}=\frac{\left.S_{1}\left(S_{2} \omega_{N}^{2}+S_{3}\right)-2 S_{4} \mid S_{2}\left(1-\omega_{N}^{2}\right)+2 \omega_{N}^{2}\right]}{S_{4}\left(S_{2}^{2}+S_{3}\right)} .
$$

The transfer function magnitude sensitivity $S_{T}^{\left|W\left(j \omega_{N}\right)\right|}$ for various values of $Q$-factor is shown graphically in Fig. 20 (curves 1, 3, 5 at $Q=1, Q=3$ and $Q=5$ respectively). It can be seen that $S_{T}^{\left|W\left(j \omega_{N}\right)\right|}$ has a maximum absolute value about two (for $\left.0 \leq \omega_{N} \leq 2\right)$. At the frequency $\omega_{N}=1(\omega=\Omega) S_{T}^{\left|W\left(j \omega_{N}\right)\right|}$ is approximately zero. 


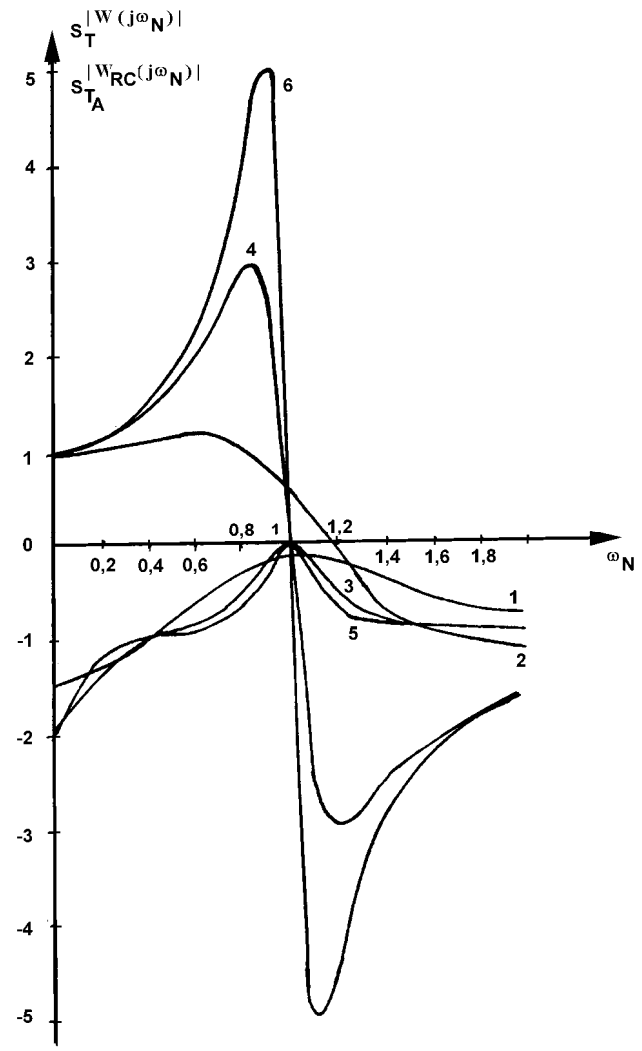

Fig. 20. Transfer function magnitude sensitivity of the second order Barber bandpass filters and the second order active bandpass filters

Similarly, from (16) and (32), considering (19), (22) and (33) the transfer function phase sensitivity with respect to time constant of a Barber passband filter of the second order is obtained:

$$
S_{T}^{\varphi\left(\omega_{N}\right)}=\frac{\omega_{N} \sqrt{S_{1}}\left\lfloor 3 S_{1}-3 \omega_{N}^{2} \cdot S_{5}-2\left(S_{5}-1\right)\left(S_{2}-2\right)\right]}{S_{5}^{2}+\omega_{N}^{2} \cdot S_{1}\left(S_{2}-2\right)} .
$$

Figure 21 shows curves of $S_{T}^{\varphi\left(\omega_{N}\right)}$ for various values of a $Q$-factor (curves 1, 3, 5 at $Q=1, Q=3$ and $Q=5$ respectively). The maximum absolute value (for $0 \leq \omega_{N} \leq 2$ ) is 0,65 . By increasing the $Q$-factor, the value of $S_{T}^{\varphi\left(\omega_{N}\right)}$ at $\omega_{N}=1$ strives to zero. 


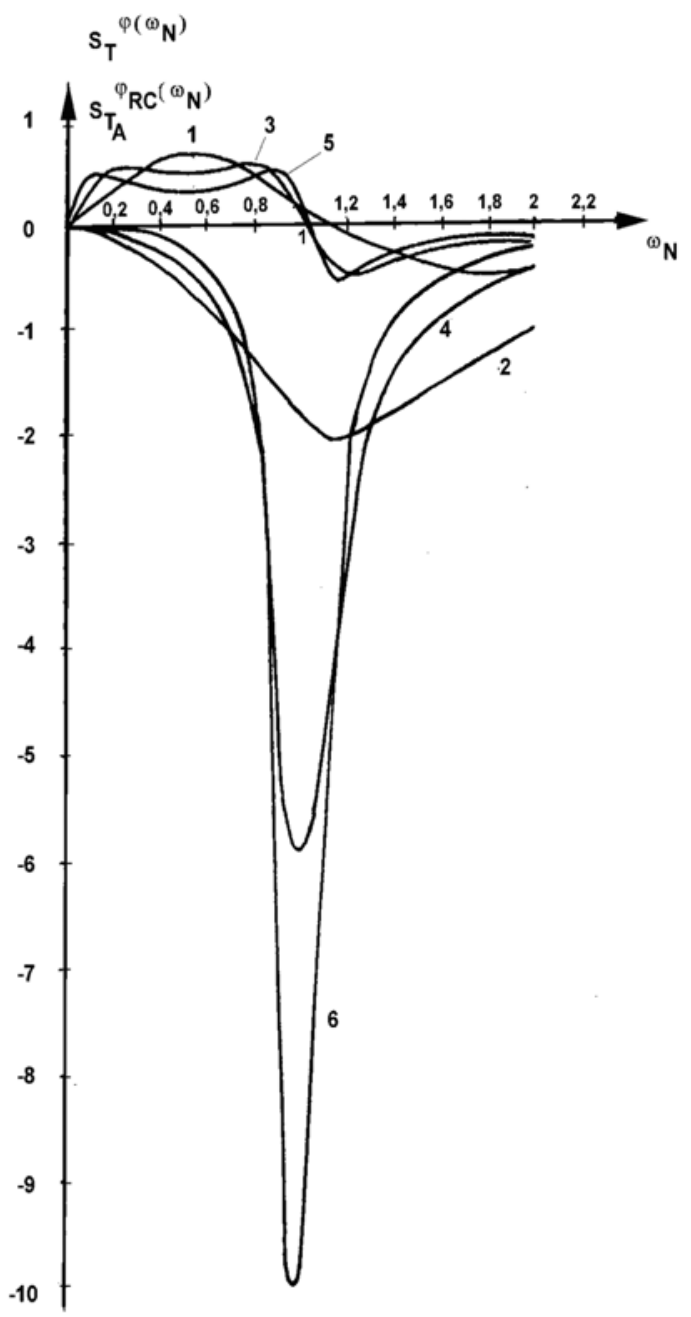

Fig. 21. Transfer function phase sensitivity of the second order Barber bandpass filters and the second order active bandpass filters

As is well known, an active filter transfer function of the second order is

$$
W_{R C}(p)=\frac{\kappa p}{p^{2}+\frac{\omega_{0}}{Q} p+\omega_{0}^{2}},
$$

or 


$$
W_{R C}(p)=\frac{p}{p^{2}+\frac{1}{Q_{A} T_{A}} p+\frac{1}{T_{A}^{2}}}
$$

where $\kappa=1$.

For comparison purposes the following relationships may be deduced:

$$
\begin{gathered}
\frac{1}{T_{A}^{2}}=\frac{1}{T^{2}}+\Omega^{2}, \\
Q_{A}=Q=\frac{T \sqrt{\frac{1}{T^{2}}+\Omega^{2}}}{2} .
\end{gathered}
$$

Using the relations (16), (22), (37), (38), and (39), the transfer function magnitude and phase sensitivity of the active filter of the second order referring to changes in the time constant $T_{A}$ are obtained respectively:

$$
\begin{aligned}
& S_{T_{A}}^{\left|W_{R C}\left(j \omega_{N}\right)\right|}=\frac{16 Q^{4}-\omega_{N}^{4}\left(4 Q^{2}-1\right)^{2}}{\left[4 Q^{2}-\omega_{N}^{2}\left(4 Q^{2}-1\right)\right]^{2}+4 \omega_{N}^{2}\left(4 Q^{2}-1\right)}, \\
& S_{T_{A}}^{\left|W_{R C}\left(j \omega_{N}\right)\right|}=\frac{2 \omega_{N} \sqrt{4 Q^{2}-1}\left[\omega_{N}^{2}\left(4 Q^{2}-1\right)+4 Q^{2}\right]}{\left[4 Q^{2}-\omega_{N}^{2}\left(4 Q^{2}-1\right)\right]^{2}+4 \omega_{N}^{2}\left(4 Q^{2}-1\right)} .
\end{aligned}
$$

Frequency behavior of $S_{T_{A}}^{\left|W_{R C}\left(j \omega_{N}\right)\right|}$ is represented in Fig. 21 (curves 2, 4 and 6 at $Q=1, Q=3$ and $Q=5$ respectively).

In Fig. 21 the graphs of $S_{T_{A}}^{\varphi_{R C}\left(\omega_{N}\right)}$ are shown (curves 2, 4 and 6 at $Q=1, Q=3$ and $Q=5$ respectively).

An examination of expressions (34), (35), (40), (41) and their comparison with the corresponding graphs show that Barber filters are more stable, especially in passband. For example, at $Q=5$ (see Fig. 20), the maximum absolute values of $S_{T}^{\left|W\left(j \omega_{N}\right)\right|}$ and $S_{T_{A}}^{\left|W_{R C}\left(j \omega_{N}\right)\right|}$ in the passband are respectively: 


$$
\begin{aligned}
& \left|S_{T}^{\mid W\left(j \omega_{N}\right)}\right| \mid=0.5, \\
& \left|S_{T_{A}}^{\mid W_{R C}\left(j \omega_{N}\right)}\right| \mid=5 .
\end{aligned}
$$

The maximum absolute values of $S_{T}^{\varphi\left(\omega_{N}\right)}$ and $S_{T_{A}}^{\varphi_{R C}\left(\omega_{N}\right)}$ (see Fig. 21) at $Q=5$ in the passband are respectively:

$$
\begin{aligned}
& \left|S_{T}^{\varphi\left(\omega_{N}\right)}\right|=0.56, \\
& \left|S_{T_{A}}^{\varphi_{R C}\left(\omega_{N}\right)}\right|=10 .
\end{aligned}
$$

Similarly, a comparison between the second order Barber lowpass filter and the second order active lowpass filter that corresponds to the same performance requirements will be made. For the purpose of the transfer function of the second order active lowpass filter will be used as follows:

$$
Y_{N F}(p)=\frac{\kappa \omega^{2}}{p^{2}+\frac{\omega_{0}}{Q_{A}} p+\omega_{0}^{2}} .
$$

Assuming (22), (38) and (39) for $\kappa=1$, the magnitude and the phase sensitivity with respect to the time constant $T_{A}$ of the second order active lowpass filter is obtained:

$$
\begin{gathered}
S_{T_{A}}^{Y_{N F}\left(\omega_{N}\right) \mid}=\frac{2 \omega_{N}^{2}\left(4 Q^{2}-1\right)\left[4 Q^{2}-2-\omega_{n}^{2}\left(4 Q^{2}-1\right)\right]}{\left[4 Q^{2}-\omega_{N}^{2}\left(4 Q^{2}-1\right)\right]^{2}+4 \omega_{N}^{2}\left(4 Q^{2}-1\right)}, \\
S_{T_{A}}^{\left|\Psi_{N F}\left(\omega_{N}\right)\right|}=\frac{2 \omega_{N} \sqrt{4 Q^{2}-1}\left[4 Q^{2}+\omega_{N}^{2}\left(4 Q^{2}-1\right)\right]}{\left[4 Q^{2}-\omega_{N}^{2}\left(4 Q^{2}-1\right)\right]^{2}+4 \omega_{N}^{2}\left(4 Q^{2}-1\right)} .
\end{gathered}
$$

Figure 18 graphically presents the magnitude sensitivity with respect to the time constant $T_{A}$ (the curves 2, 4, 6 at $Q=0.6, Q=0.8, Q=1$ ). 
The frequency behavior of $S_{T_{A}}^{\Psi_{N F}\left(\omega_{N}\right)}$ is shown in Fig. 19 (curves 2, 4, 6 at $Q=0.6, Q=0.8$ and $Q=1$ respectively).

From the expressions (29), (30), (43), (44) and Fig. 18 and Fig. 19 it can be seen that the active lowpass filter is less stable than the corresponding Barber lowpass filter. Increasing the $Q$-factor, $S_{T_{A}}\left|Y_{N F}\left(j \omega_{N}\right)\right|$ increases in the passband.

The maximum values of $S_{T_{A}}^{\Psi_{N F}\left(\omega_{N}\right)}$ and $S_{T}^{\Psi\left(\omega_{N}\right)}$ in the passband are respectively:

$$
\begin{gathered}
S_{T_{A}}^{\Psi_{N F}\left(\omega_{N}\right)}=2, \\
S_{T}^{\Psi_{N F}\left(\omega_{N}\right)}=0.9 .
\end{gathered}
$$

It is obvious that for low values of the $Q$-factor, it is not possible to obtain a great advantage with respect to the stability characteristics in the passband of the second order Barber lowpass filter.

Experimentally and theoretically obtained results were in good accordance in bread range of changes $Q, \omega, T$ and $\Omega$.

\section{CONCLUSION}

The Barber filters described in this paper have a low sensitivity. That is a basic condition for use of them in measurements in moving objects, for example, in aeroplanes, in satellites, in rockets etc. Applications of these filters make possible the creation of filter systems containing many channels with identical AFC and PhFC which have a high stability and can be simply controlled by changing the modulation function. That insures highly effective filtering. As can be seen from the presented material, their most appropriate function is to use them as bandpass filters. At the same time the Barber filters represent examples of how systems of high selectivity with lower $Q$ circuitry can be obtained. 


\section{REFERENCES}

[1] N. F. Barber, Narrow band-pass filter using modulation, Wireless Engr., 24, 132134 May (1947).

[2] G. S. Lukic, Theoretical bases of the Barber Filters, Signal Proccesing, 78 139149 (1999).

[3] L. E. Franks, I. W. Sandberg, An alternative approach to the realization of network transfer functions: The N-path filter, Bell Sys. Tech. J., 39, 1321-1350, September (1960).

[4] G. B. Madella, Single-phase and polyphase filtering devices using modulation, Wireless Engineer, 24, October (1947).

[5] O. V. Kustov, V. Z. Lundin, Operacionne usiliteli v lineinih cepiah, Svjaz, Moskva, 108-111 (1978).

[6] E. von Langer, Zeitmultiplexverfahren zur Filter-synthese, Frequenz, 20 (1966).

[7] K. von Mohrmann, W. Heinlein, N-phad-filter Hoher Selektivität mit Spulenlosen Schwingkreisen, Frequenz, 21 (1967).

[8] G. A. Rigby, Integrated selective amplifiers using frequency translation, IEEE Journal of Solid-State Circuits, $\mathbf{S}_{\mathbf{c}}-\mathbf{1}, 1,(1966)$.

[9] K. S. Kongelbeck, G. S. Szentirmai, Synthesis of modulation filters, IEEE Trans. Circuit Theory, CT-19, 155-161 (1972).

\section{Р е $з$ и м е}

\section{АНАЛИЗА НА ЧУВСТВИТЕЛНОСТА НА БАРБЕРОВИТЕ ФИЛТРИ}

Изучена е чувствителноста на Барберовите филтри кои во литературата се среќаваат и под други називи (на пр. квадратурни, синхрони, модулациони, параметриски итн.). Најдено е дека чувствителноста на филтрите зависи од нивниот ред како и од типот на применетите апроксимации. Меѓутоа, како што е покажано во трудот, чувствителноста не зависи позначително од редот на филтерот.

Направена е споредба на чувствителноста на традиционалните активни филтри од втор ред и Барберовите филтри од втор ред. Земена е предвид чувствителноста на преносната функција во однос на временската константа $T$ затоа што вредноста на оваа константа е најнестабилна величина.

Предноста на Барберовите филтри во однос на чувствителноста е очигледна, особено кај Барберовите појасни филтри. Поради нивната мала чувствителност, Барберовите филтри се мошне корисни за мерења во објекти во движење (авиони, сателити, ракети и слично). 
Клучни зборови: анализа на чувствителност; Барберови филтри; функција на пренос; апроксимации; фреквенција на модулација; Барберови појасни филтри; Барберов нископојасен филтер; активен појасен филтер; активен нископојасен филтер; фактор на квалитет $Q$; споредба

Adress:

Gordana Lukić

Technical College Zagreb,

Konavoska 2, 10000 Zagreb, Croatia

Received: 2. XII 2004

Accepted: 19. XII 2005

Прилози, Одд. мат. тех. науки, XXVII-XXVIII, 1-2 (2006-2007), стр. 67-91 